\title{
Interethnic Discourse and Cosmology in Indigenous Association Practices in the Amazon: Hutukara Yanomami Association
}

\author{
Felipe Nascimento Araujo \\ Social Anthropology Graduate Program, Brasilia National University \\ (Programma de Pós-Graduação em Antropologia Social Universidade de Brasilia)
}

etropic 14.2 (2015): 53- 62. http://www.reefandleaf.com.au/etropic.html \& http://www.jcu.edu.au/etropic

\begin{abstract}
I propose in this article to journey from the cosmological elements present in indigenous interethnic political discourse to indigenous association practices. The paper will seek to understand the bases of the indigenous association praxis, and to give an overview of the historical trajectory of indigenous political 'protagonism' in Brazil. To discuss the development of a political discourse of so many different peoples as comprise indigenes of Brazil may seem like a reckless generalisation. However, there is one thing they share in common: the history of contact with western civilization. This history is not singular, but plural. So many facts, widespread all over the continent, form a shared experience, and from this emerge a discourse which I seek to understand.
\end{abstract}

\section{Interethnic Discourse and Indigenous Associations}

Today there are hundreds of indigenous associations in Brazil, associations in the Western sense of the term of a free association of citizens formally recognised by the State. ${ }^{1}$ What's behind the emergence of these associations is, among other factors, the growing indigenous role in the national political arena, allowing them to appropriate organisational forms and social roles played within the Western civilisation's tradition - the civil situation. The relative success in establishing an inter-ethnic dialogue between indigenous societies and the Brazilian State - as well, in a wider perspective, between indigenous peoples and the national society which encompasses the State but whose interethnic interaction dynamics can occur without any relation with the State - is the main cause of this 'protagonism'. One of the factors that led to the establishment of this dialogue was the gradual construction and enunciation of a political discourse directed "out," i.e, "for whites". But the construction of this discourse "out" was preceded by a first moment of a cosmologic reflection about the contact "for inside" through speech and narrative2: what the anthropologist Bruce Albert in the Yanomami case, called a "symbolization ethnocentric". This development of a contact

\footnotetext{
${ }^{1}$ See the Instituto Socioambiental's website indicated in the Reference List, for an updated list of associations.

${ }^{2}$ Nadia Farage says the fundamental difference between discourse and narrative is that the content of the first is contemporary, and the content of the second is the mythical past (oral communication with Janaina F.

Fernandes, member of the examination board of the dissertation Northeast Landscapes: Almofala of Tremembé and Tremembé Almofala). This paper stresses that interethnic political discourse, pronounced in order to achieve effects in the present, includes elaborations on the mythical past, the historical facts and the future - and prophetic reworkings of myths.
} 
cosmological discourse "for inside" made possible, in a second moment, the "symbolization relativistic and dependent, incorporating the white models of ethnification and Indianness" (Albert, 2000, p. 242). So there is a change of perspective: from the elaboration of the other to $u s$, there is a shift to the elaboration of us to the other.

Here I use the notion of "for inside" as the internal practices, i.e., practices realised in the indigenous societies internal extent - not in the interethnic contact sphere. Practices and dialogues where the interpersonal interactions and interactions between collectives occur between individuals and collectives of the same indigenous society. I also use the term "white" in a wider sense: interaction with the "white" is the interaction with the dominant society. The interaction with the dominant society here encompasses the interaction with Brazilian society, with national and international capitalistic networks, with international entities of many types (missionaries, 'indigenists', environmentalists and financial supporters), and, finally, with the Brazilian State.

Here we are concerned with the way in which indigenous associations enunciate and practice this interethnic discourse, and the implications in the political practices "for out", as well as the implications of the enunciation of this discourse "for inside", i.e., in the cosmologies of indigenous societies. Questions that arise from this research include: what is the relationship between the creation of indigenous associations and the enunciation/practice of an interethnic discourse? In what context, and how is the political interethnic discourse formulated? What is the relationship between interethnic discourse and cosmology?

The anthropologist Dominique Gallois, who has been working with the Wayãpi people (Tupi) since 1975, points out that the indigenous political discourse brings together elements from mythical and historical discourses (Gallois, 2000, p.212-213) to support claims and actions. This points towards a direction in the analysis of interethnic political discourse. We can think it: (a) contains elements from the Amerindian cosmologies, (b) contains undeniable information about catastrophic contact history facts, (c) these elements are intertwined in a way to legitimate these claims, but also in a way to singularise the discourse in itself, through its content giving it a different form and aesthetic than that of the white (western) discourse.

Here we can hear the first singularity of this discourse, because it is realised as a double elaboration: the cosmology incorporates the interethnic contact by diverse means in its multiple systems of explanation, and, inversely, the indigenous discourse about the contact, and the indigenous "secular" conception about the contact, are elaborated within this explanatory system. Moreover, there is a transversality between the interethnic politic discourse creation and its enunciation/practice in the national political arena and the advent of indigenous associations. So this advent and the enunciation/practice of interethnic politic discourse marks a second stage of the interethnic contact between indigenous societies and the Brazilian State. The emergence of this discourse and its relations with the emergence of indigenous associations will be analysed here based on the discourse of the shaman and political leader Davi Kopenawa Yanomami and the activities of the Hutukara Yanomami Association (HAY), founded by him and a group of Yanomami political leaders in 2004. I had the opportunity to work with these leaders as an advisor between 2012 and 2013.

\section{Indigenous Associations: Indigenous Societies Against the State}


The change in the dynamics of the relationship between South American indigenous societies and National States has been emerging since the 1980s. The essence of this change was a shift towards a proactive interaction with the entering into the national political stage and the construction of a discourse and creation of associations, among other forms of political 'protagonism'. Prior to the 1980s the principal interactions between indigenous societies and the State usually occurred when indigenous territories were invaded and the people directly impacted by this invasion - whether in the form of governmental projects of economic development (the construction of roads, hydroelectric schemes, electricity transmission lines and so on), or by the expansion of the national frontier of production (agrarian, cattle breeding, mining, and so on), not necessarily subsidised by the State.

During this period there took place an indigenous political mobilisation which became increasingly widespread in Brazil. Indigenous interethnic leaders tailored their first partnership with 'indigenist' and environmentalist partners and shaped their discursive lines which serve as frame for dialogue with the State. The main objective, in many cases, was territorial guarantees through the creation of Indigenous Lands (Terras Indígenas). During the 1990s and continuing into the 2000s the creation of indigenous associations has intensified. One of the features of what could be called the "indigenous political movement" in Brazil is that indigenous mobilisations take place at a local and regional level, and the creation of indigenous associations shows these features. In some cases there is an articulation between local associations through institutions created for this purpose, like the Negro River Indigenous Organisations Federation (Federação das Organizações Indígenas do Rio Negro - FOIRN) and the Brazilian Amazon Indigenous Organisations Coordination (Coordenação das Organizações Indígenas da Amazônia Brasileira COIAB). The Indigenous Peoples from Brazil Association (Associação dos Povos Indígenas do Brasil APIB) articulates mainly political manifestations in the federal capital Brasília. The indigenous political mobilisation profile in Brazil is still that of organisations of local or regional actuation: associations that represent specific communities, certain people, or particular indigenous lands.

During the 1990s and 2000s the demarcation of lands was also a challenge for many indigenous people. Land demarcation could not put an end to cases of invasion of land and other crimes perpetrated against indigenous people. A new moment of diversification of dialogue with the State took place in this moment, for it was after the demarcation of lands that indigenous associations were first created - and continue to be created. Indian peoples were challenged with the necessity of diversification in interactions with the State when education, health, land management and territorial protection policies began to be implemented by the State. The claims discourse now needs to comprise strategies to horizontalize these policies.

The diversification in interaction includes that of the white interlocutors for indigenous rights, as well as the indigenous association's actions. The discourse itself began to diversify. There is a shift from an almost unimodal chord, that of the demarcation of lands and the removal of invaders, to a plurimodal chord. In this chord the dialogue with the State becomes oriented to the control of these policies. There also began a more institutionalised relationship with national and international 'indigenist' and socio-environmentalist organisations in which the most varied projects and programs are carried out: territorial management and monitoring; education projects - oftentimes bilingual - and cultural revitalization; healthcare programs and so on. 
It is with the support of these entities that indigenous associations make contact with international sponsor organisations to procure financial resources to their projects. Through analysing the kinds of projects that are taken over by the indigenous associations and partner institutions we can see a parallel between these projects and the State policies, while some projects, mainly related with health, occupy a void left by the omission of the State. The preparation and process characteristics of interethnic discourse "out" are perhaps evidence of the practice of indigenous associations.

\section{Interethnic Discourse: First Consideration}

The practice of interethnic political discourse can be thought as the practice of cosmopolitics, and the practice of cosmopolitics can be seen as the creation of a praxis in which cosmological elements and political elements are developed based on historical factors.

\section{Cosmopolitcs: Mythical Languages and Historical Facts in Words of Shamans and Interethnic Leaders}

The term cosmopolitcs is used here to signify processes developed in the moment in which the indigenous cosmology enters in the sphere of the relationship between indigenous and State. This moment is no longer in the endogenous elaborations about contact, but in the elaboration of a political discourse enunciated in the national political arena. I deliberately exclude from the notion of cosmopolitcs the processes which are developed in the relationship between indigenous and national societies that are not mediated directly by the State. What I call here cosmopolitics is similar to the notion of ethnopolitics, but rather it brings discursive elements that don't come from the construction of identity's processes, but from the cosmology in the proper sense of the term, that is elements from the cosmology are also brought to the construction of identity's process. In this sense, cosmopolitics could be considered as an ethnopolitical component. Interethnic political discourse would be the practice of cosmopolitics under inter-ethnic dialogue with the State.

However, we need to go deeper into the different meanings attributed to the cosmopolitic if we want to understand the phenomenon it signifies. There is another meaning attributed to cosmopolitics, away from the sphere of interethnic relations. A meaning that delineates what we could call the nuclear dimensions of this practice: shamanism. Eduardo Viveiros de Castro (2008) corresponds cosmopolitics as shamanism's agency. He sees the shaman as a cosmopolitics diplomat. If in Amerindian cosmopolitics we have the animist assumption that "other beings besides the humans - notably animal species - are provided with intentionality and conscience, and in this sense are persons, i.e., in terms of social relations" (de Castro, 2008, p.13) so we could see that "being capable to see as the other species see themselves like humans - the shamans of each specie play the role of cosmopolitic diplomat, operating in an arena where different "socionatural" interests confront each other" (de Castro, 2008, p.17).

A reading of one of Joanna Overing's Works (1990) about the Piaroa people (Karib) inspires a way of thinking about a possible resemblance between shamans and interethnic leaders. According to Overing, O Ruwang (a Piaroa shaman) "assembled unique versions of worlds by drawing together particular strands of the "before time" history of creator gods and the "today time" history of people and animals, in order to protect his community from disease" (Overing, 1990, p.602). Thus the shaman builds versions of the world to inside, i.e, to the 
community environment. The interethnic leader, who may or not may be a shaman, besides this endogenous movement, also performs this construction through interethnic political discourse in the interethnic political sphere - the dialogue with the State. The shaman is a producer of knowledge and his/her work, notably the production of cosmological explanations about phenomenon of all kinds - including the phenomenon of interethnic contact - is essential to the construction of interethnic political discourse. The same movement produces the interethnic political discourse and actualizes the cosmology. Both demand the intertwining of cosmological elements and historical and present facts of contact.

\section{Hutukara Associação Yanomami: Political and Cosmological}

The creation of Hutukara Associação Yanomami is an emblematic example of the new kind of relationship between indigenous societies and nation states in the late twentieth and early twenty-first century. It was founded in 2004 by the interethnic political Yanomami leader Davi Kopenawa, with the support of local Yanomami leaders on one side, and, on the other, 'Indigenist' partner organisations. The Pro-Yanomami Park Creation Commission (Comissão para Criação do Parque Yanomami CCPY) was integral in this process, as was the participation of "local" leaders - in which the spectrum of influence varies, but generally this refers to a regional leadership, recognised by a group of communities.

Davi Kopenawa had the political sense of bringing together Hutukara leaders from different regions of the Yanomami Indigenous Territory, in addition to the core family of his own village. Here, Yanomami demographics need to be briefly outlined. According to the Special Yanomami Health District/Indigenous Health Department (Distrito Sanitário Especial Yanomami/Secretaria de Saúde Indígena) in 2011 the population of Yanomami on Yanomami Indian Land totaled 19,338 people, living in 248 communities, spread out across Yanomami Indigenous Territory which is more than 9,500 km2. This demonstrates the importance of bringing together leaders from different regions of indigenous land to achieve political success in actions that aim to impact the lives of the whole Yanomami society.

The legitimacy of his speech/action rests through grounding in a double foundation. It unites the appropriated white way of doing politics, duly registered with the state bureaucracy in a National Register of Legal Entities (Cadastro Nacional de Pessoa Jurídica), with an interethnic discourse that brings the indigenous cosmology as a legitimising feature of its uniqueness.

In the first moment of the period we are analyzing between the Yanomami society and the State, we witness the cessation of the genocide caused by the gold-panners' invasion of the Yanomami territory in the 1980s and the demarcation of the Yanomami Indigenous Land (Terra Indígena Yanomami). This political background was the main objective of Davi Kopenawa's speech and of his alignment with local leaders and 'indigenist' and environmentalist partners in order to maintain a dialogue with the State.

And in this first moment is also a shamanic approach to an ecological ideology and an interethnic dialogue between Yanomami society and the State through Davi Kopenawa's discourse (Albert, 2000). At this time we can see the legitimation of Yanomami claims through the singularisation of its discourse by the appropriation and twist of the concept of Nature, a strategy by which Davi Kopenawa approached environmentalists and gained 
political support: working Nature as “productive misunderstanding”, as Bruce Albert evaluates (Albert, 2000: p.257-261).

Today this dialogue has shifted in another direction, creating a new sphere of relations between Yanomami society and the State. The aim is for any kind of control and participation in public policy implemented in the Yanomami social context, but not always thought through or engineered through a Yanomami perspective. Over the decades of the 1990s and 2000s, with the Indigenous Territory already demarcated and approved, the State began to formulate and implement - in more or less effective ways - education programs, public policy on health, territorial management and welfare programs. One of the most significant issues was the vertical feature of this process: there was no dialogue (or a deaf one); Yanomami peoples were excluded from this process. It was within this political context that the Hutukara Associação Yanomami was created.

It is not possible here to do a detailed analysis of the entire role played by the cosmological elements in the relation between Hutukara and the State, or to describe the whole argumentative scope managed by the coordinators in their interlocution with government institutions and their many staff, managers and politicians. However, let me summarize these roles in an overview on Hutukara actions. When we talk about the Hutukara's collective interethnic political discourse we are actually talking about a rhizomatic, multiple, collectively created discourse with its individual singularities of each coordinator in dialogues with different governmental institutions. Following is an outline of various actions - as with rhizomatic analysis these areas of action are intertwined, but they basically concern education, health, natural resources and welfare.

The State only began to implement public policies in education from the end of the 2000s. Up until this period the State merely reacted to non-governmental education projects seeking official recognition or support. Examples include the Magistério Yarapiari (in partnership with CCPY), a teacher training program, and also the Intercultural Bilingual Education Program (Programa de Educação Intercultural e Bilíngue) - a program focusing on literacy created and carried out by the Cooperation and Service, a small non-indigenous Association, with Yanomami People. Other examples that are important to mention include education programs carried out by religious entities like Missão Evangélica da Amazônia (MEVA) and Missão Novas Tribos do Brasil.

Today there is an incipient net of municipal schools inside the Terra Indígena Yanomami (Indigenous Yanomami Territory) with Yanomami teachers. But this net, coming from vertical public policies, is detached from the Yanomami social reality. Inefficiency in the management of public resources to maintain and expand this net, the calculated dismantling (misuse of public money), or even the mere lack of interest of the public functionaries, prevents this educational framework/ideal from flourishing. As the face of this net, shed classrooms falling apart and inactive Yanomami teaching staff, may indicate a lack of identification with the educational frame proposed/imposed. Here the focus needs to be on the lack of intercultural efforts by the State to create and implement these policies, there is even a lack of a satisfactory dialogue between the experiences already carried out and the State. Hutukara, in the education field, faces the challenge of obtaining a State's official recognition of these educational initiatives. In this way Hutukara seeks to obtain an effective space inside the State, a space to participate in the creation, implementation and development of public educational policies. 
In the health sphere, after the regularization of the Terra Indígena Yanomami in 1992, the public health policy oriented for the Yanomami society was basically outsourcing services of the extinct FUNASA (National Health Foundation) to non-governmental organizations. FUNASA replayed the resources to these organizations. From 2009, with the extinction of FUNASA and the creation of Secretarias de Saúde Indígena (Indigenous Health Secretaries), there was also created the Distrito Sanitário Especial Yanomami (Yanomami Public Health Special District), the Indigenous Health Sub-System's executive arm inside the Terra Indígena Yanomami. This District has a Deliberative Council, in which leaders from all regions of the Terra Indigena Yanomami take chairs (in order to facilitate the work, the District divides the Terra Indigena Yanomami into regions). However, the political conduct of the District health activities and its formulations causes the participation of these Yanomami leaders to become null. There are dramatic cases of administrative dishonesty and mismanagement. The hiding of this corruption impels the District administrative staff to keep the Yanomami leaders away from the administrative sphere. Hutukara seeks to carry out a social control of the District policies before seeking an interethnic dialogue in the direction of formulating health policies with true contribution and engagement from Yanomami.

In another direction within the health sphere, Hutukara works on the diffusion (for out) and circulation (for inside) of notions of shamanic cosmological health/illness, and also Yanomami knowledges about forest medicine (plants, animals, fungus, and so on). These activities are also developed in partnership with various institutions and researchers. Examples of positive outcomes are the realization of shaman meetings and the production of numerous materials - mostly audio-visual and papers - in partnership with the Instituto Socioambiental (See References below).

Since the late 1980s - motivated by political and economical interests on subsoil mineral resources and the rich rainforest wood resources of the Yanomami territory - a geopolitical situation has arisen. While the Terra Indigena Yanomami was recognized and demarcated, some types of natural reserves were created overlapping it. In Brazil, in accordance with the National System of Conservation Unities (SNUC) there are many kinds of reserves - from those of integral protection to ones designated to natural resource "sustainable" management.

The Parque Nacional do Pico da Neblina (National Part of Pico da Neblina), a reserve of integral protection, overlaps the southwest of the Terra Indígena. The geopolitical problem concerns which group has jurisprudence over this area: the Instituto Chico Mendes de Biodiversidade (Biodiversity Chico Mendes Institute), the governmental institutions responsible for the management of reserves, or the Yanomami. However, some Yanomami leaders offer a different idea about the reserves bordering the Terra Indígena, including the National Park Serra da Mocidade, the Ecological Station of Caracaraí, the Ecological Station of Niquiá, and the Ecological Station of Maracá. They think of these reserves as buffer zones for pressures like gold-panners' or farmers' invasions. Nonetheless the dialogue with the State institutions responsible for environment policies is precarious and insufficient to provide any real participation of the Yanomami in policies. Finally, the Floresta Nacional Amazonas (Amazonas National Forest) is thought by many researchers (see Albert \& Le Tourneau, 2009) to be Trojan horse: now they are "sleeping", but the land can be claimed by those who have interest in exploring the natural resources of the Terra Indígena Yanomami south-central area. The Floresta Nacional kind of conservation unit (nature reserves) is a sustainable management one. 
However, it is the welfare policies which are the strongest demonstrations of vertical policies. Policies elaborated to another social context - such as urban and rural - are implemented with no dialogue with Indians and their leaders. The point is not whether they are efficient or not (according to what criteria?), good or not, claimed or not; what I want to emphasise is that they are implemented with no participation of the Yanomami society. The Bolsa Famíla and retirement policies are notable examples.

The above examples - in all their complexity - demonstrate the creation of Associations brings an appropriate channel to this new and contemporary relationship with the State. Associations channel a multiple dialogue which must face each state policy to the Yanomami society, and more, must face the whole Brazilian political context in order to defend Yanomami rights and maintain political conquests. The diversification of the relationship with the State becomes visible in the Hutukara structure of coordinations. There are five coordinations: Education, Health, Territorial Management, Communication and Administrative. The first four are responsible for activities related to the dialogue with State and with any kind of activities in order to defend Yanomami rights. While each one of these coordinations is responsible to different kind of activities, they work in an intertwined manner, especially in the sphere of monitoring public policies. In this kind of activity we can see the character of interlocutor of State.

\section{Interethnic Discourse as Political Practice: Final Considerations}

In the Hutukara case both relations with the State and with some sectors of dominant society - mainly in the case of 'indigenists' and environmentalist partners like the Instituto Socioambiental and international institutions of financial sponsorship such as the Rainforest Foundation - are placed through the enunciation and practice of an interethnic discourse.

We must recognize some differences in the relationship between Hutukara and State, and, in a wider sphere, the so-called dominant society. Firstly, the interethnic discourse that brings the Yanomami cosmology to the political sphere is enunciated in order to achieve a control of public policies in a effort to horizontalize the production, implementation and execution of public policies; to achieve a effective participation of Yanomami society in these policies. The presence of cosmological elements in the discourse is particularly visible in the dialogue within the spheres of education, health, welfare, and territorial protection. Cosmological elements are also brought to the dialogue with 'indigenist' and environmentalist partners and sponsorship institutions.

However, in dialogue with State institutions responsible for the policing and security of territory, for instance in the case of the remove-invaders of the Terra Indígena Yanomami, this kind of discourse is not enunciated. The dialogue established in this situation is pragmatic, based on the 'indigenist' legal scope which guarantees to Indians the exclusive use of their land's surface. Thus, in conjunct action with Federal Police, for example, the cosmological elements of the interethnic dialogue are underlying, un-enunciated. The presence of these elements on the above interethnic discourse - the one by which the conquest of the Terra Indígena Yanomami was reached - are part of historical facts that resulted in this situation: the State being responsible for removal of invaders from their land.

The indigenous political protagonisms of the last four decades challenge anthropologists to 
fuse cultural perspectives of the studies of culture with interethnic relations studies. Now we can no more distinguish, neither ethnographically nor theoretically, one sphere from the other. The studies of "culture" with "tradition" prioritizing "autochthonous" elements language, art, mythology (?) - must be connected with the "contact situation” elaborated by Balandier, which inspired Roberto Cardoso de Oliveira in the elaboration of the idea of interethnic friction. Only in this way one can understand the new reality of the indigenous peoples of Brazil.

\section{Works Cited}

Albert, B. \& Milliken, W. (2009). Urihi a. A terra-floresta Yanomami. São Paulo: ISA IRD.

Albert, B. (2000) [1995]. O ouro canibal e a queda do céu: uma crítica xamânica da economia política da natureza. In: A. R. Ramos \& B. Albert (Eds) Pacificando o Branco: Cosmologias do contato no norte-amazônico (pp.239-270). São Paulo: Edunesp/IRD/Imprensa Oficial.

Albert, B. (1992) A fumaça do metal. História e representações do contato entre os Yanomami, Anuário Antropológico 89, 151-189.

Cardoso de Oliveira, R. (1981) [1964]. O Índio e o Mundo dos Brancos, (3 ${ }^{\mathrm{a}}$ Edição). Brasília: Editora Universidade de Brasília.

Carneiro da Cunha, M. (2009). Cultura com aspas. São Paulo: Cosacnaify.

Clastres, P. (2012) [1974]. Sociedade contra o Estado. São Paulo. Cosac Naify.

Erikson, P. (2000). Reflexos de si, ecos de outrem. Efeitos do contato sobre a autorepresentação Matis. In: A. R. Ramos \& B. Albert (Eds) Pacificando o Branco: Cosmologias do contato no norte-amazônico (pp.179-204). São Paulo: Edunesp/IRD/Imprensa Oficial.

Ferreira, H. P. (Ed.) (2011). Dicionário de Verbos Português-Yanomama: napë thãaxo, yanomama thãaxo, thëkipëã wëanowei siki. São Paulo. Instituto Socioambiental.

Gallois, D. T. (2000). “Nossas falas duras”: Discurso politico e auto-representação Waiãpi. In: A. R. Ramos \& B. Albert (Eds) Pacificando o Branco: Cosmologias do contato no norte-amazônico (pp. 205-237). São Paulo: Edunesp/IRD/Imprensa Oficial.

Hugh-Jons, S. (1994). Shamans, Prophets, Priests and Pastors. In: Thomas, In: C. Humphrey (Ed.). Shamanism, History and the State (pp.32-75). Ann Arbor: The University of Michigan Press.

Kopenawa, D. \& Albert, B. (2013). The Falling Sky: Words of a Yanomami Shaman. Cambridge Massachusets, Cambridge, UK. The Belknap Press of Harvard University Press.

Lévi-Srauss, C. (1972) [1962]. El pensamiento selvage. México. Breviários, Fondo de Cultura Económica.

Menezes, E. S. de. (2014). Os “piaçabeiros” no médio Rio Negro: identidade étnica e conflitos territoriais, Paralelo 15, Brasília. Dissertação de Mestrado defendida na Universidade Federal do Amazonas, Manaus.

Overing, J. (1990). The Shaman as a Maker of Worlds: Nelson Goodman in the Amazon. Man, New Series, 25 (4), 602-619.

Souza, M. C. de. (2007). A Dádiva Indígena e a Dívida Antropológica: O Patrimônio Cultural entre Direitos Universais e Relações Particulares SÉRIE ANTROPOLOGIA 415. Brasília: Universidade de Brasília. 
Viveiros de Castro, E. (2008). Xamanismo transversal: Lévi-Strauss e a cosmopolítica amazônica. In, R.C. de Queiroz \& R. F. Nobre. Lévi-Strauss: Leituras Brasileiras. Editora UFMG, Belo Horizonte.

Turner, T. (1993). De cosmologia a história: resistência, adaptação e consciência social entre os Kayapó. In, Viveiros de Castro, E. \& Carneiro da Cunha (Eds) 14 Amazônia: Etnologia e história indígena (pp.43-66). São Paulo: NHII/Universidade de São PauloFapesp.

\section{Websites}

http://pib.socioambiental.org/pt/c/iniciativas-indigenas/organizacoes-indigenas/lista-de-or Não há fontes bibliográficas no documento atual.ganizacoes (Accessed January, 2015) http://www.portal.saude.gov.br (Accessed, 2011) 